Wioletta KILAR

Akademia Pedagogiczna, Kraków

\title{
Koncentracja przestrzenna światowych firm informatycznych
}

Zmieniające się uwarunkowania funkcjonowania światowej gospodarki w zasadniczy sposób wpływają na kierunki jej przemian. „Postępujący proces rozwoju społeczno-gospodarczego związany z przechodzeniem z fazy postindustrialnej do fazy informacyjnej przejawia się w powstawaniu nowych sektorów gospodarczych oraz instytucji” (Zioło 2004, s. 97). Długofalowy proces kształtowania się nowoczesnej gospodarki uzależniony jest w dużym stopniu od rozwoju sektora informacyjnego oraz od działań, zjawisk i procesów związanych z tworzeniem i wykorzystaniem nowoczesnych technologii, w tym technologii informatycznych w różnych dziedzinach gospodarki, które przyczyniają się do przemian w metodach gospodarowania przedsiębiorstw (Zorska 2003).

Rozwój społeczno-gospodarczy związany jest z postępującymi procesami globalizacji, w których podstawową rolę odgrywają korporacje ponadnarodowe, organizujące światową przestrzeń gospodarczą, społeczną i kulturową poprzez różne systemy sieciowych powiązań przestrzenno-produkcyjnych. Wśród wiodących korporacji światowych znaczącą rolę odgrywają korporacje sektora informatycznego, które zajmują drugą pozycję wśród sektorów gospodarczych reprezentowanych przez wiodące przedsiębiorstwa. Wśród 1000 największych korporacji światowych reprezentują ten sektor 104 firmy o przeciętnej wartości rynkowej 24 mld USD. Należy nadmienić, iż pierwszą pozycję wśród sektorów zajmują instytucje finansowe, reprezentowane przez 245 firmy, na trzecim miejscu zaś znajdują się korporacje reprezentujące sektor artykułów luksusowych, skupiający 141 przedsiębiorstw (Zioło 2006).

W świetle przedstawionych przesłanek w niniejszych rozważaniach podjęta zostanie analiza koncentracji przestrzennej światowych firm informatycznych. Zmierzać będziemy do określenia ich zróżnicowania pod względem wielkości potencjału, rodzajów i rozmiarów działalności oraz stopnia koncentracji w przestrzeni światowej ${ }^{1}$.

Przyjęte do badań 100 największe firmy informatyczne świata² łącznie wykazują 1,2 bln USD przychodów, generując 140 mld USD zysku (tab. 1). Rozpatrując wysokość przychodów w poszczególnych firmach, zauważa się dużą rozpiętość ich potencjału ekono-

\footnotetext{
${ }^{1}$ Podstawową bazą empiryczną są dane z rankingu Infotech 100 z 2005 r., publikowanego przez Business Week.

${ }^{2} \mathrm{~W}$ zestawieniu ujęto firmy, których przychody osiągnęły co najmniej $300 \mathrm{mln}$ USD. Ostatecznie lista objęła 500 przedsiębiorstw. Podzielono je wg 8 kategorii branżowych. Jeżeli cena akcji danej spółki spadła o ponad $75 \%$ lub jej przychody ze sprzedaży zmniejszyły się, firma ta nie była uwzględniana w zestawieniu Infotech 100 BusinessWeek. Odrzucono też te spółki, w wypadku których przygotowujący ranking mieli wątpliwości co do
} 
micznego, wyrażającego się wahaniem wartości przychodów od 524,7 mln USD do 97,0 mld USD, tj. jak 1:185 (ryc. 1). Średnio w ciagu roku w badanych przedsiębiorstwach nastapił wzrost przychodów o 12,1 mld USD, tj. do 133,5\%. Wśród nich czołowe miejsce zajmuje korporacja IBM, jeden z największych na świecie producent sprzętu komputerowego, której przychody wynosiły 97,0 mld USD, tj. 8,0\% ogółu przychodów. Kolejne pozycje zajmują: Verizon Communications (jeden z największych operatorów telekomunikacyjnych w Stanach Zjednoczonych) o przychodach 72,4 mld USD (6,0\%), następnie Deutsche Telekom $(5,9 \%)$ i Samsung Electronics (5,9\%). Wymienione korporacje łącznie skupiają znaczną część potencjału ekonomicznego, koncentrując 313,0 mld USD, tj. 25,9\% ogółu przychodów największych korporacji informatycznych. Najniższymi przychodami wynoszącymi poniżej 1 mld USD odznaczają się dwa amerykańskie przedsiębiorstwa: SRA International i Cognizant Technology Solutions, indyjskie Satyam Computer Services oraz tajwańska Novatek Microelectronics, które łącznie skupiają 0,3\% udziału w ogóle przychodów.

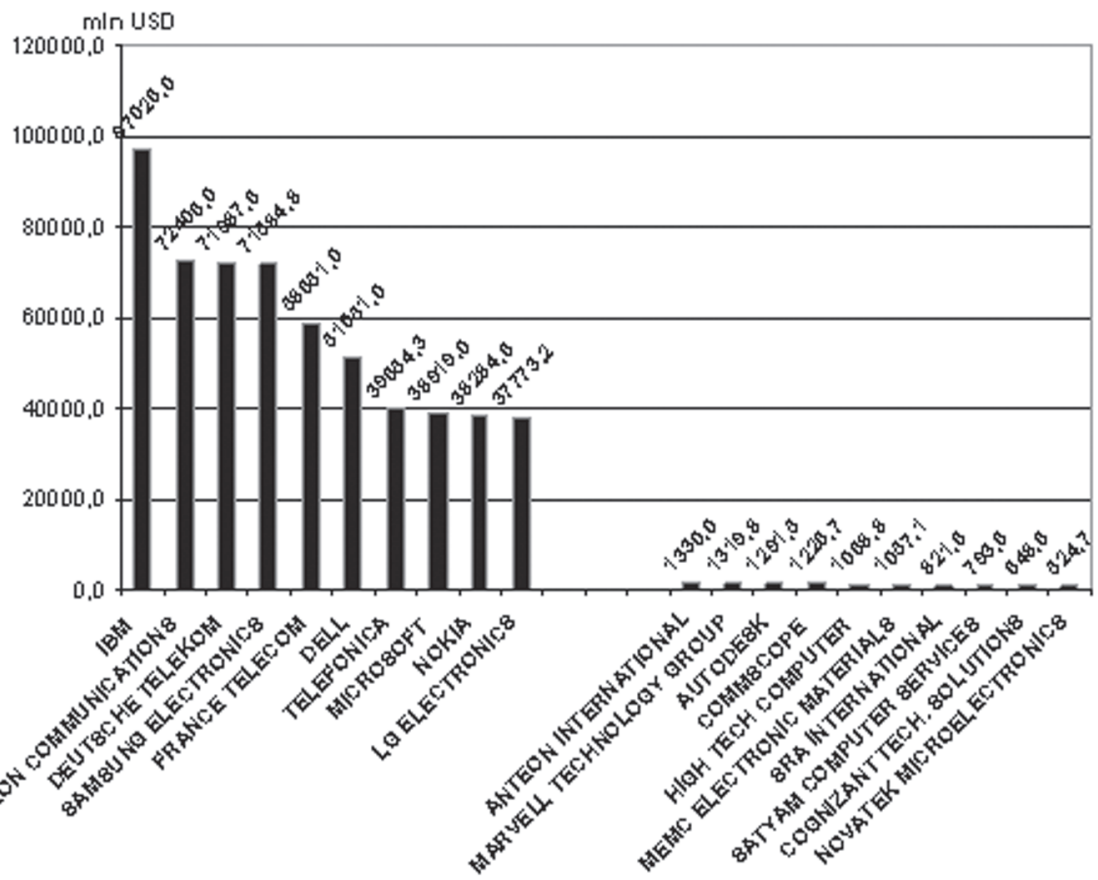

Ryc. 1. Zróżnicowanie przychodów światowych korporacji informatycznych w 2005 r.

Źródło: opracowanie własne na podstawie Infotech 100 BusinessWeek, 2005 r.

O rozwoju potencjału tego sektora świadczy dynamika wzrostu przychodów w 100 największych firmach informatycznych: w latach 2004-2005 wahała się od 100,6 do 250,0\%. Najwyższą dynamiką wzrostu wynoszącą $250,0 \%$ cechuje się firma Powerchip Semiconductor, która jest największym tajwańskim wytwórcą układów pamięci. Na drugiej pozy-

przyszłych wyników. Pominięto również telekomy o monopolistycznej (lub bardzo do niej zbliżonej) pozycji, która zapewnia im nieuczciwą przewagę nad rywalami. 
cji znajduje się kanadyjska firma Research In Motion, znana przede wszystkim z produkcji palmtopów (komputerów kieszonkowych) BlackBerry, której przychody wzrosły do 227,1\%, a na trzecim miejscu korporacja Google, utożsamiana głównie z wyszukiwarką internetową, odznaczająca się wzrostem przychodów do 203,0\%. Znacznym wzrostem przychodów od 190,0 do $150,9 \%$ charakteryzuje się 16 kolejnych przedsiębiorstw, które łącznie skupiają 4,2\% ogółu przychodów. Najniższa dynamika (od 104,8 do 100,6\%) cechuje firmy: Nokia, Segate Technology, Deutsche Telecom, France Telecom oraz BT Group, skupiające łącznie 17,3\% udziału w ogóle przychodów.

Podobnie dużym zróżnicowaniem potencjału analizowane firmy odznaczają się pod względem osiąganych zysków. Łączne zyski analizowanych korporacji informatycznych wynoszą 140,1 mld USD i wahają się one od 12,4 mln do 11,2 mld, tj. jak 1: 903 USD (ryc. 2). Najwyższym zyskiem odznacza się korporacja Microsoft, który wynosi 11,2 mld USD, tj. 8,0\% zysku wszystkich badanych firm. Na drugiej pozycji znajduje się Samsung Electronics, które wygenerowało zysk w wysokości 9,4 mld USD, tj. 6,7\% ogółu, zaś trzecią IBM, z zyskiem wynoszącym 8,2 mld USD, tj. 5,9\% ogółu zysków. Łącznie te 3 największe korporacje obejmują 28,9 mld USD, tj. 20,6\% ogółu zysków. Kolejną grupę tworzą Intel, Verizon Communications, Cisco Systems, Deutsche Telecom oraz China Mobile z zyskiem od 7,9 do 7,0 mld USD, które łącznie skupiają 23,2\% ogółu zysków. Duża grupa, bo aż 69 firm, miała zyski poniżej 1 mld USD, stanowiąc poniżej 1\% w ogóle.

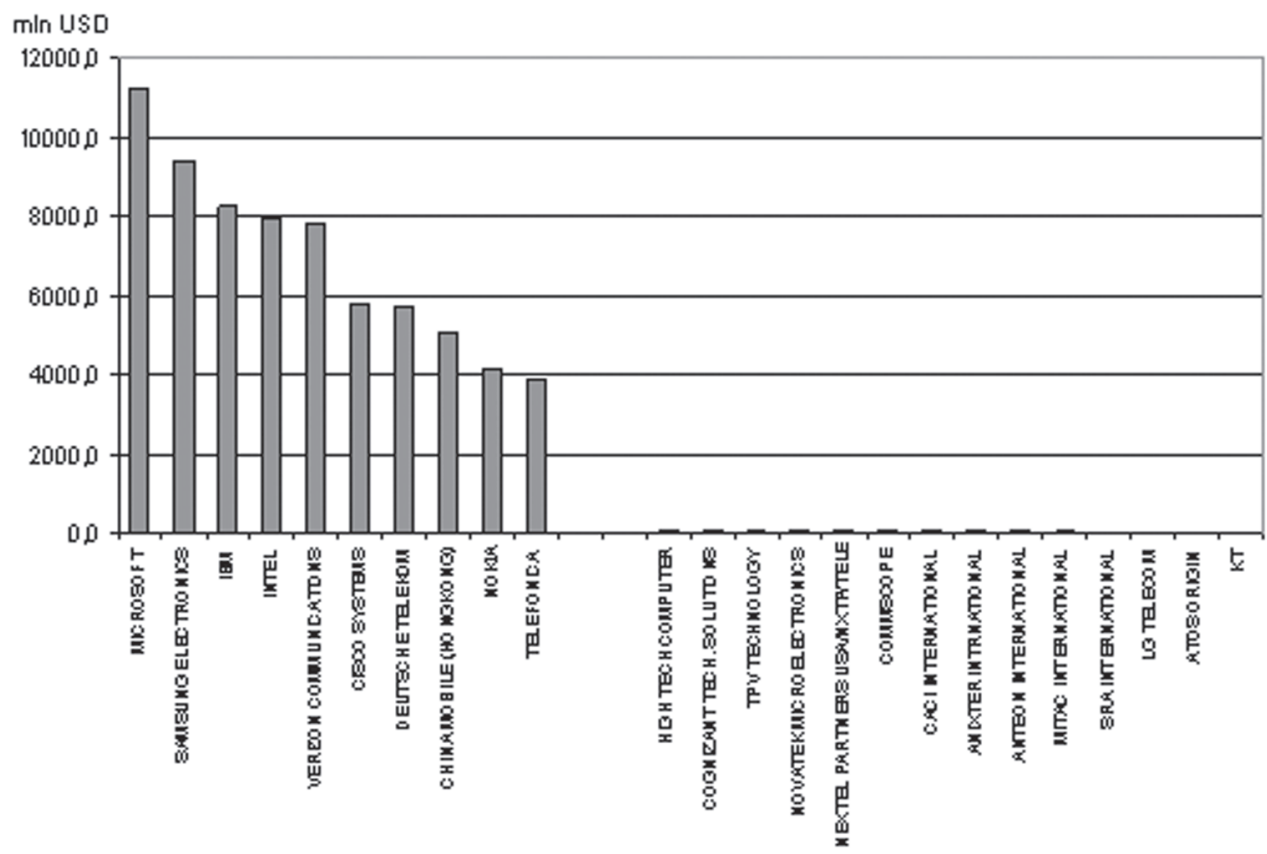

Ryc. 2. Zróżnicowanie zysków wśród 100 największych światowych korporacji informatycznych w 2005 roku

Źródło: opracowanie własne na podstawie Infotech 100 BusinessWeek, 2005 r. 
Analizowane korporacje charakteryzują się dużym stopniem zależności między przychodami a zyskami, czego wyrazem jest wysoki wskaźnik korelacji, który wynosi 0,832 (ryc. 3). Natomiast mniejszy stopień zależności wstępuje w korporacjach największych, które charakteryzują się przychodami ponad 20 mld USD i zyskiem ponad 4 mld USD, co ilustruje znacznie niższa wartość korelacji, wynosząca 0,318 .

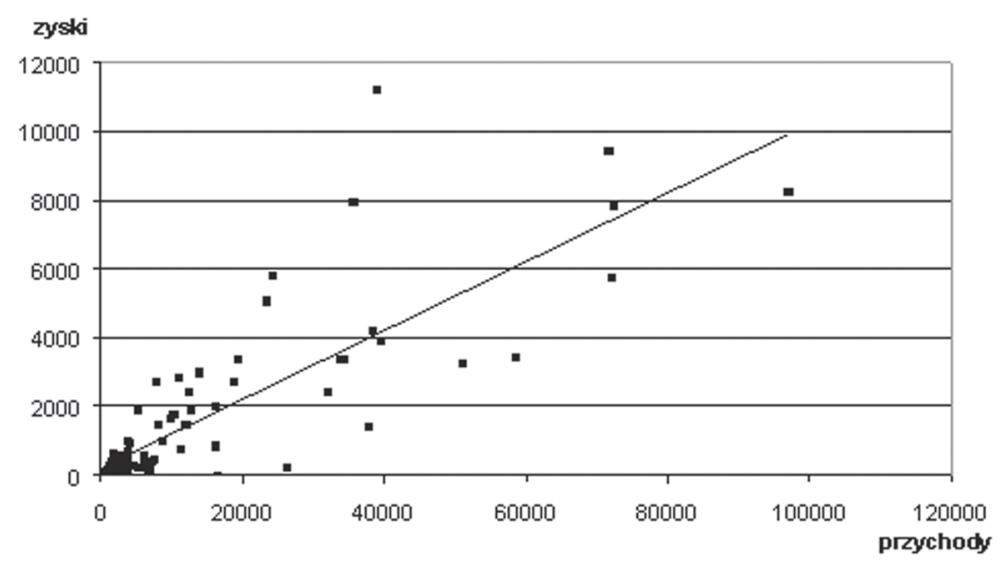

Ryc. 3. Korelacja pomiędzy przychodami a zyskami poszczególnych korporacji informatycznych (w mln USD)

Źródło: opracowanie własne na podstawie Infotech 100 Business Week, 2005 r.

Biorąc pod uwagę zróżnicowanie działalności analizowane przedsiębiorstwa reprezentuje 8 grup w sektorze informatycznym (tab. 2).

Tab. 2. Rodzaje działalności 100 największych korporacji informatycznych w 2005 r.

\begin{tabular}{|c|l|r|r|r|r|r|r|}
\hline L.p. & \multicolumn{1}{|c|}{$\begin{array}{c}\text { Rodzaje } \\
\text { działalności }\end{array}$} & $\begin{array}{c}\text { Liczba } \\
\text { firm } \\
\text { w sek- } \\
\text { torze }\end{array}$ & $\begin{array}{c}\text { Przychody } \\
\text { w mln USD }\end{array}$ & $\begin{array}{c}\text { Zysk } \\
\text { w mln } \\
\text { USD }\end{array}$ & $\begin{array}{c}\text { Udział } \\
\text { w ogóle } \\
\text { przy- } \\
\text { chodów } \\
(\%)\end{array}$ & $\begin{array}{c}\text { Udział } \\
\text { w ogóle } \\
\text { zysków } \\
(\%)\end{array}$ & $\begin{array}{c}\text { Efektywność } \\
\text { przychodów }\end{array}$ \\
\hline 1. & Telekomunikacja & 24 & 428197,0 & 46460,4 & 35,4 & 33,2 & 9,22 \\
\hline 2. & $\begin{array}{l}\text { Komputery i urza- } \\
\text { dzenia peryferyjne }\end{array}$ & 24 & 300893,7 & 24314,8 & 24,9 & 17,4 & 12,37 \\
\hline 3. & Półprzewodniki & 16 & 94066,8 & 18375,3 & 7,8 & 13,1 & 5,12 \\
\hline 4. & Usługi & 14 & 148225,5 & 13477,1 & 12,2 & 9,6 & 11,00 \\
\hline 5. & $\begin{array}{l}\text { Sprzęt telekomuni- } \\
\text { kacyjny }\end{array}$ & 10 & 133790,0 & 18122,7 & 11,1 & 12,9 & 7,38 \\
\hline 6. & Oprogramowanie & 7 & 66587,1 & 17186,4 & 5,5 & 12,3 & 3,87 \\
\hline 7. & Spółki internetowe & 3 & 9122,9 & 1873,5 & 0,8 & 1,3 & 4,87 \\
\hline 8. & Dystrybutorzy & 2 & 29625,9 & 304,8 & 2,4 & 0,2 & 97,20 \\
\hline & Ogółem & 100 & 1210508,9 & 140115,0 & 100,0 & 100,0 & 8,64 \\
\hline
\end{tabular}

Źródło: obliczenia własne na podstawie Infotech 100 Business Week, 2005 r. 
Wśród nich dominujące znaczenie mają 24 firmy telekomunikacyjne, których łączna wartość przychodów wynosi 428,2 mld USD, tj. 35,4\% ogółu przychodów, a zyski 46,5 mld USD, tj. 33,2\% ogółu zysków (ryc. 4). Kolejną pozycję zajmuje grupa: komputery i urządzenia peryferyjne, która reprezentowana jest również przez 24 przedsiębiorstwa, obejmujące 24,9\% ogółu przychodów (300,9 mld USD) i 17,4\% ogółu zysków (24,3 mld). Te dwa rodzaje działalności odgrywają dominującą rolę w strukturze światowych firm informatycznych, obejmując łącznie $60,2 \%$ ogólnej wartości przychodów i 50,5\% ogólnej wartości zysków. Mniejszy udział ma 14 firm zajmujących się serwisem (usługi), których udział w ogóle przychodów wynosi 12,2\%, a zysków 9,6\%. Podobnym potencjałem odznacza się grupa: sprzęt telekomunikacyjny, której udział w ogóle przychodów wynosi 11,1\%, a w zyskach 12,9\%. Zdecydowanie większy udział w zyskach aniżeli w ogólnym udziale przychodów mają takie rodzaje działalności, jak produkcja półprzewodników i oprogramowanie. Skupiają one łącznie 13,3\% ogólnych przychodów, ich zyski obejmują 25,4\%. Najmniejszą rolę w tym względzie mają dystrybutorzy i spółki internetowe, które reprezentowane są przez 5 firm, a łączna wartość ich przychodów wynosi 38,7 mld USD, tj. 3,2\% ogółu przychodów, oraz 2,2 mld USD zysku, tj. 1,6\% ogółu zysków.

Poszczególne rodzaje działalności reprezentowane przez analizowane korporacje odznaczają się bardzo zróżnicowaną efektywnością przychodów ${ }^{3}$, wahającą się od 97,2 do 3,9 (tab. 2). Najwyższą efektywnością cechuje się 2 korporacje, reprezentujące dystrybutorów $(97,2)$. Kolejny rodzaj działalności, tj. komputery i urządzenia peryferyjne, charakteryzuje się 8 razy mniejszą efektywnością przychodów, wynoszącą 12,4. Podobną wartością tego wskaźnika cechują się usługi $(11,0)$ oraz telekomunikacja $(9,2)$. Kolejną grupę stanowią: sprzęt telekomunikacyjny, półprzewodniki i spółki internetowe, których efektywność przychodów wynosi od 7,4 do 4,9. Najniższą efektywnością $(3,9)$ odznaczają się korporacje produkujące oprogramowania.

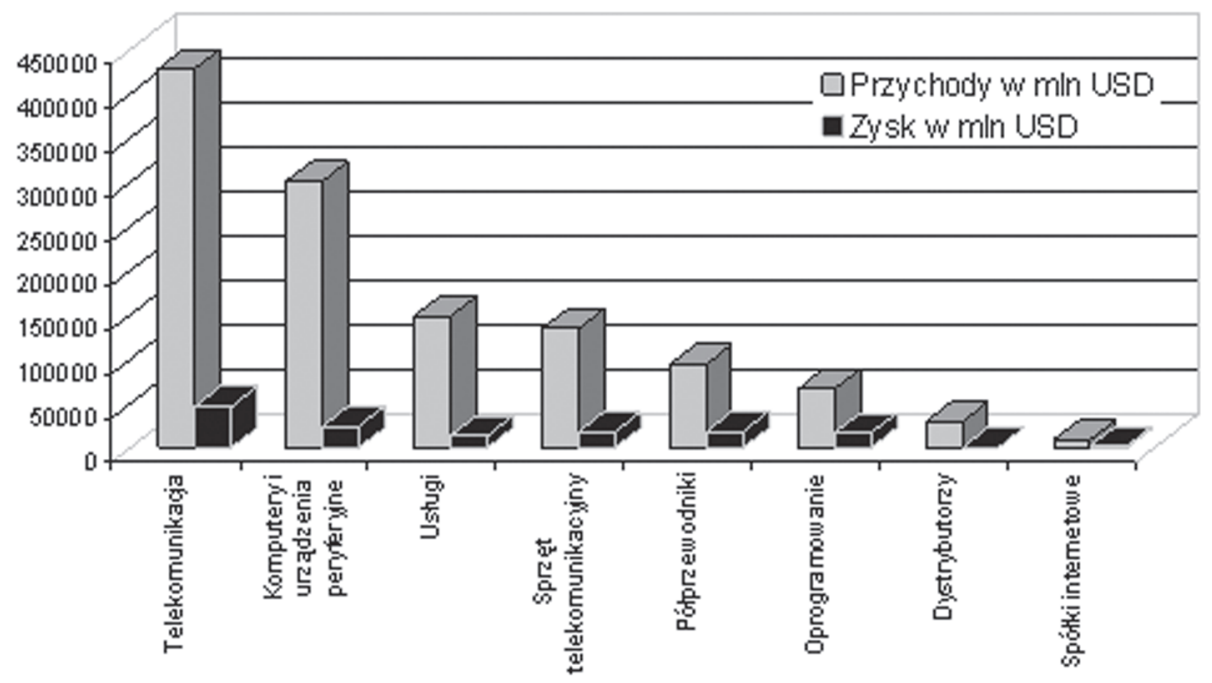

Ryc. 4. Przychody i zyski korporacji informatycznych w poszczególnych grupach

Źródło: opracowanie własne na podstawie Infotech 100 BusinessWeek, 2005 r.

${ }^{3}$ Efektywność przychodów $=$ przychody $/$ zyski 
Analizowane korporacje mają siedziby swoich zarządów na terenie 23 państw, w 9 krajach europejskich, 8 azjatyckich, 5 w Ameryce Północnej i Środkowej oraz 1 w Oceanii. Najwyższą koncentracją siedzib zarządów odznaczają się Stany Zjednoczone, na terenie których skupia się 44 siedziby zarządów analizowanych korporacji, oraz Tajwan - 12 siedzib zarządów (tab. 3). Łącznie te dwa państwa odznaczają się największą koncentracją siedzib ponadnarodowych firm informatycznych, skupiając ich 56\% analizowanych firm. Następną grupę stanowi Japonia, Korea i Indie, na terenie których występuje od 5 do 6 siedzib zarządów analizowanych korporacji, które łącznie obejmują 16\%. Trzecią grupę reprezentuje 8 krajów: Bermudy, Kanada, Rosja, Niemcy, Meksyk, Hiszpania, Francja i Chiny, na terenie których działają 2-3 siedziby zarządów. W pozostałych 10 krajach znajduje się po 1 siedzibie zarządu korporacji (Finlandia, Holandia, Hongkong, Indonezja, Nowa Zelandia, Szwajcaria, Szwecja, Turcja, Wielka Brytania i Kajmany).

Tab. 3. Liczba korporacji, przychodów i zysków

100 największych światowych korporacji informatycznych wg państw

\begin{tabular}{|c|c|c|c|c|c|c|c|c|}
\hline L.p. & Kraj & $\begin{array}{c}\text { Liczba } \\
\text { kor- } \\
\text { poracji }\end{array}$ & $\begin{array}{l}\text { Przychody } \\
\text { w mln USD }\end{array}$ & $\begin{array}{c}\text { Zysk } \\
\text { w mln } \\
\text { USD }\end{array}$ & $\begin{array}{l}\text { Udział } \\
\text { w ogóle } \\
\text { przycho- } \\
\text { dów (\%) }\end{array}$ & $\begin{array}{c}\text { Udział } \\
\text { w ogóle } \\
\text { zysków } \\
(\%)\end{array}$ & $\begin{array}{c}\text { Przychody } \\
\text { na 1 firme } \\
\text { (mln USD/1 } \\
\text { firmę) }\end{array}$ & $\begin{array}{c}\text { Zyski na } \\
1 \text { firmę } \\
\text { (mln } \\
\text { USD/ } \\
1 \text { firmę) }\end{array}$ \\
\hline 1. & USA & 44 & 524782,2 & 69594,6 & 43,4 & 49,7 & 11926,9 & 1581,7 \\
\hline 2. & Tajwan & 12 & 65401,9 & 6397,1 & 5,4 & 4,6 & 5450,2 & 533,1 \\
\hline 3. & Japonia & 6 & 55185,1 & 5437,7 & 4,6 & 3,9 & 9197,5 & 906,3 \\
\hline 4. & Korea & 5 & 133841,1 & 11111,9 & 11,1 & 7,9 & 26768,2 & 2222,4 \\
\hline 5. & Indie & 5 & 8209,2 & 1759,3 & 0,7 & 1,3 & 1641,8 & 351,9 \\
\hline 6. & Bermudy & 3 & 21202,5 & 1098,5 & 1,8 & 0,8 & 7067,5 & 366,2 \\
\hline 7. & Kanada & 3 & 9710,8 & 997,9 & 0,8 & 0,7 & 3236,9 & 332,6 \\
\hline 8. & Niemcy & 2 & 81662,3 & 7445,0 & 6,7 & 5,3 & 40831,2 & 3722,5 \\
\hline 9. & Hiszpania & 2 & 55845,9 & 5945,1 & 4,6 & 4,2 & 27923,0 & 2972,6 \\
\hline 10. & Meksyk & 2 & 24240,0 & 3899,9 & 2,0 & 2,8 & 12120,0 & 1950,0 \\
\hline 11. & Chiny & 2 & 22028,0 & 3537,3 & 1,8 & 2,5 & 11014,0 & 1768,7 \\
\hline 12. & Francja & 2 & 65245,3 & 3475,7 & 5,4 & 2,5 & 32622,7 & 1737,9 \\
\hline 13. & Rosja & 2 & 6033,6 & 1373,1 & 0,5 & 1,0 & 3016,8 & 686,6 \\
\hline 14. & Hongkong & 1 & 23229,2 & 5071,8 & 1,9 & 3,6 & 23229,2 & 5071,8 \\
\hline 15. & Finlandia & 1 & 38284,6 & 4186,0 & 3,2 & 3,0 & 38284,6 & 4186,0 \\
\hline 16. & \begin{tabular}{|l|} 
Wlk. \\
Brytania \\
\end{tabular} & 1 & 34356,1 & 3359,4 & 2,8 & 2,4 & 34356,1 & 3359,4 \\
\hline 17. & Szwecja & 1 & 18724,7 & 2739,6 & 1,5 & 2,0 & 18724,7 & 2739,6 \\
\hline 18. & Indonezja & 1 & 3802,2 & 686,5 & 0,3 & 0,5 & 3802,2 & 686,5 \\
\hline 19. & \begin{tabular}{|l|} 
Nowa \\
Zelandia \\
\end{tabular} & 1 & 3784,6 & 544,6 & 0,3 & 0,4 & 3784,6 & 544,6 \\
\hline 20. & Turcja & 1 & 3353,2 & 514,1 & 0,3 & 0,4 & 3353,2 & 514,1 \\
\hline 21. & Holandia & 1 & 3393,8 & 396,6 & 0,3 & 0,3 & 3393,8 & 396,6 \\
\hline 22. & Kajmany & 1 & 6710,0 & 394,0 & 0,6 & 0,3 & 6710,0 & 394,0 \\
\hline \multirow[t]{2}{*}{23.} & Szwajcaria & 1 & 1482,6 & 149,3 & 0,1 & 0,1 & 1482,6 & 149,3 \\
\hline & Ogółem & 100 & 1210508,9 & 140115,0 & 100,0 & 100,0 & 14345,1 & 1401,2 \\
\hline
\end{tabular}

Źródło: obliczenia własne na podstawie Infotech 100 Business Week, 2005 r. 
Przedstawiona analiza wskazuje, iż siedziby zarządów korporacji informatycznych skupiają się głównie w dwóch światowych centrach, w Stanach Zjednoczonych i Kanadzie oraz na Dalekim Wschodzie. Sporadycznie występują na terenie państw europejskich. Natomiast brak ich na obszarze Ameryki Południowej, Australii i Afryki. Nierównomierne rozmieszczenie największych firm informatycznych w przestrzeni światowej nawiązuje generalnie do poziomu rozwoju gospodarczego, zasobów pracy oraz uwarunkowań ekonomicznych. Potrzeba tworzenia tego typu firm wiąże się bowiem bardzo ściśle z poziomem rozwoju gospodarki i wynika przede wszystkim ze zróżnicowanych uwarunkowań przestrzeni światowej. Przedstawione kraje charakteryzują się znacznym zróżnicowaniem pod względem potencjału ekonomicznego korporacji, których siedziby znajdują się na ich terenie.

Biorąc pod uwagę zróżnicowanie przychodów wg państw, na terenie których występują siedziby zarządów największych firm informatycznych, zauważa się dominację przychodów korporacji, których siedziby znajdują się w Stanach Zjednoczonych. Przychody tych firm wynosiły 524,8 mld USD, tj. 43,4\% ogółu przychodów (ryc. 5). Drugą pozycję zajmuje Korea, - 5 zarządów analizowanych korporacji, które skupiają 11,1\% ogółu przychodów (133,8 mld USD). Następną grupę korporacji tworzą Niemcy, Tajwan, Francja, Hiszpania, Japonia i Finlandia, ich przychody wynoszą od 4 do 7\% w ogóle przychodów i łącznie wynoszą 29,9\%. Znacznie niższe przychody (od 34,3 mld USD do 18,7 mld USD) cechowały korporacje z siedzibami zarządów w Wielkiej Brytanii, Meksyku, Hongkongu, Chinach, na Bermudach oraz w Szwecji, gdyż skupiają łącznie 11,9\% ogółu przychodów. Najniższe przychody, wynoszące poniżej 10 mld USD, uzyskały firmy, których siedziby zarządów znajdują się w Kanadzie, Indiach, na Kajmanach, w Rosji, Indonezji, Nowej Zelandii, Holandii, Turcji i Szwajcarii - skupiają łącznie jedynie 3,8\% ogółu przychodów.

Podobnym zróżnicowaniem charakteryzują się poszczególne kraje pod względem zysków. Dominujące znaczenie pod tym względem mają korporacje, których siedziby zarządów znajdują się w Stanach Zjednoczonych. Łączny udział w ogóle zysków tych firm wynosi 49,7\% (podczas gdy udział w przychodach wynosi 43,4\%, a w ogólnej liczbie korporacji 44\%). Podkreśla to rolę firm amerykańskich odznaczających się znaczną przewagą w zakresie osiaganych zysków przez analizowane firmy (ryc. 6). Na drugiej pozycji pod tym względem znajduje się Korea, z której 5 korporacji wygenerowało 7,9\% ogólnej wartości zysków. Łączne zyski korporacji z tych dwóch krajów wynosiły 80,7 mld USD, tj. 57,6\% ogólnej wartości zysków. Na kolejnych miejscach znajdują się państwa, z których przedsiębiorstwa wygenerowały zyski wynoszące od 3,0 do 6,0\% ogółu zysków. Do tej grupy należą: Niemcy, Tajwan, Hiszpania, Japonia, Hongkong i Finlandia, a łączny ich udział w zyskach wynosi 24,6\% ogółu. Następnie występują kraje, w których analizowane korporacje wypracowały zyski od 1,0 do 32,9\% ogółu, należą do tej grupy: Meksyk, Chiny, Francja, Wielka Brytania, Szwecja, Indie i Rosja. Najniższymi zyskami, stanowiącymi poniżej 1\% w ogólnych zyskach wypracowanych przez 100 największych korporacji informatycznych, cechują się firmy, których siedziby zarządów znajdują się na terenie Bermudów, Kanady, Indonezji, Nowej Zelandii, Turcji, Holandii, Kajmanów i Szwajcarii.

Poszczególne kraje odznaczają się zróżnicowanym potencjałem ekonomicznym poszczególnych korporacji, co wyraża przeciętna wartość przychodów na 1 korporację, która waha się od 1,5 mld USD do 40,8 mld USD (tab. 3, ryc. 7). Najwyższymi wartościami wskaźnika charakteryzują się Niemcy (40,8 mld USD) i Finlandia (38,3 mln USD). Następna grupa krajów charakteryzuje się wskaźnikiem o wartości od 34,3 do 18,7 mld USD, należą 


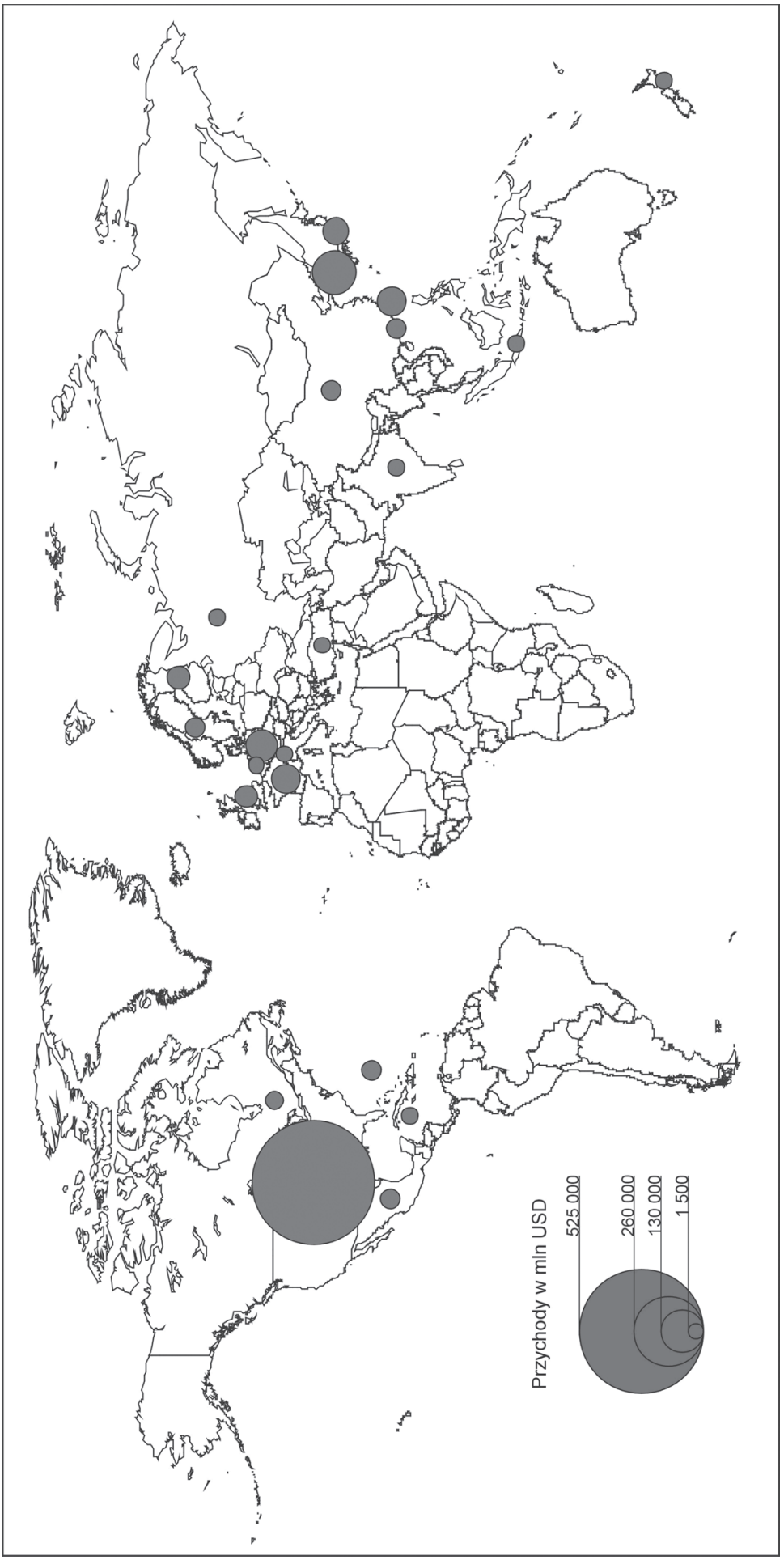

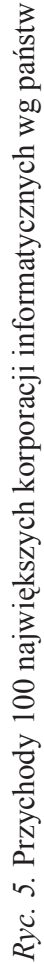

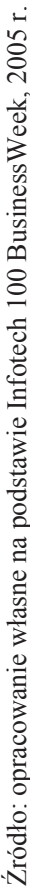




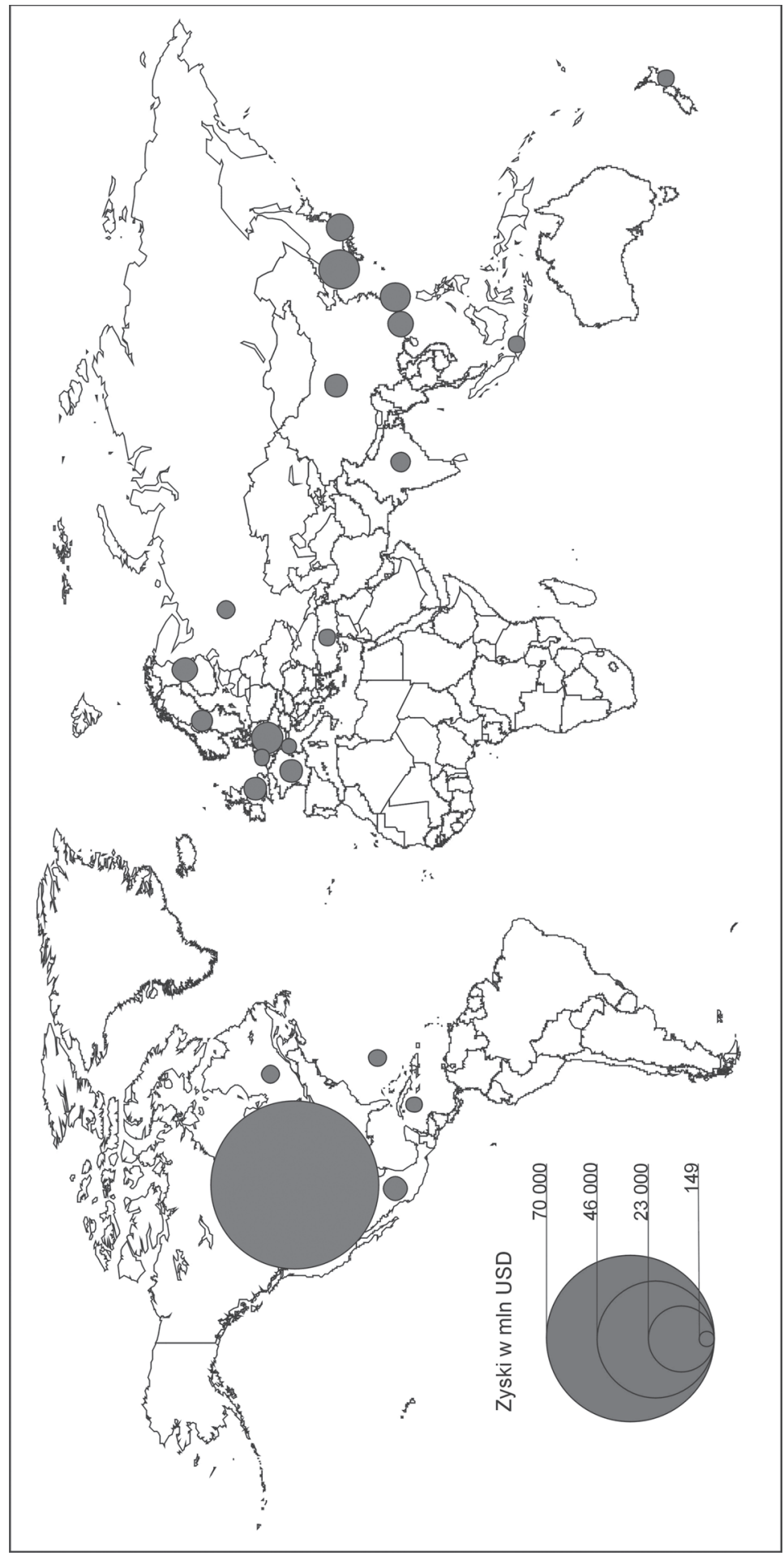

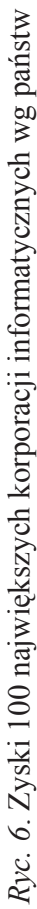

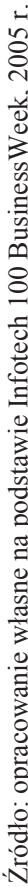


do niej Wielka Brytania, Francja, Hiszpania, Korea, Hongkong i Szwecja. Niższe wartości (od 12,1 mld do 5,5 mld USD) odznaczały Meksyk, Stany Zjednoczone i Chiny. Pozostałe kraje charakteryzowały się wskaźnikiem poniżej 4 mld USD, najniższymi wartościami cechowały się wśród nich Indie i Szwajcaria.

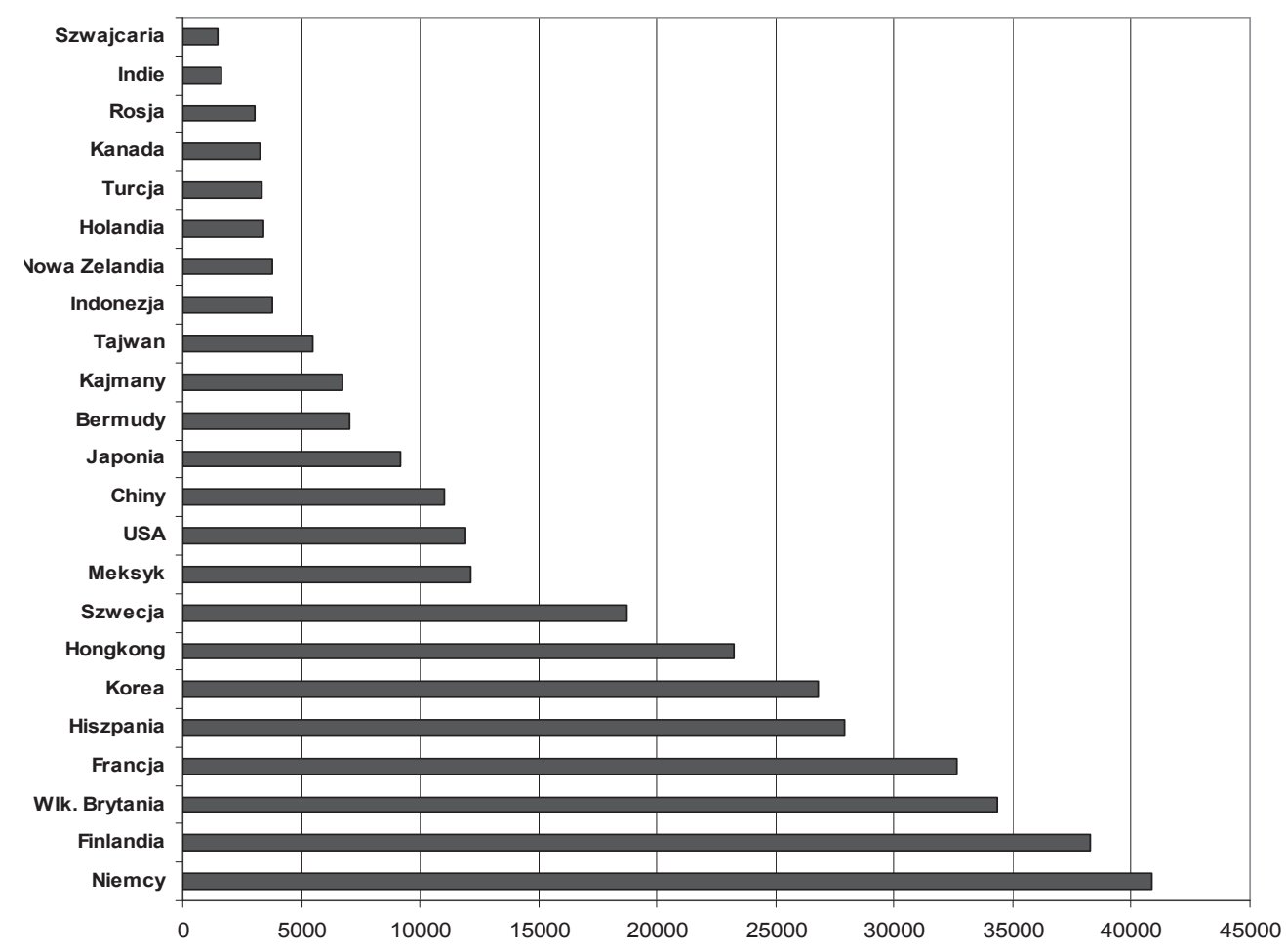

Ryc. 7. Wskaźnik przychodów na 1 korporację wg państw w 2005 r.

Źródło: opracowanie własne na podstawie Infotech 100 BusinessWeek, 2005 r.

Nieco odmienny obraz przedstawia wskaźnik przeciętnej wartości zysków na 1 korporację, który waha się od 5,1 mld USD do 149,3 mln USD (ryc. 8). Najwyższe wartości cechują Hongkong (5,1 mld USD) oraz Finlandię (4,2 mld USD). Niemcy, Wielka Brytania, Hiszpania, Szwecja, Korea, Meksyk, Chiny, Francja i Stany Zjednoczone charakteryzują się zyskiem przypadającym na 1 korporację w danym kraju wynoszącym od 3,7 do 1,6 mld USD. Kolejną grupę stanowią kraje, w których wartość wskaźnika wynosi od 906,3 do 514,1 mln USD, należą do niej: Japonia, Rosja, Indonezja, Nowa Zelandia, Tajwan i Turcja. Znacznie niższa wartość wskaźnika (od 396,6 do 332,6 mln USD) charakteryzuje pozostałe 5 państw, tj. Holandię, Kajmany, Bermudy, Indie, Kanadę. Natomiast najniższe zyski wypracowała korporacja szwajcarska i wynoszą one jedynie 149,3 mln USD. 


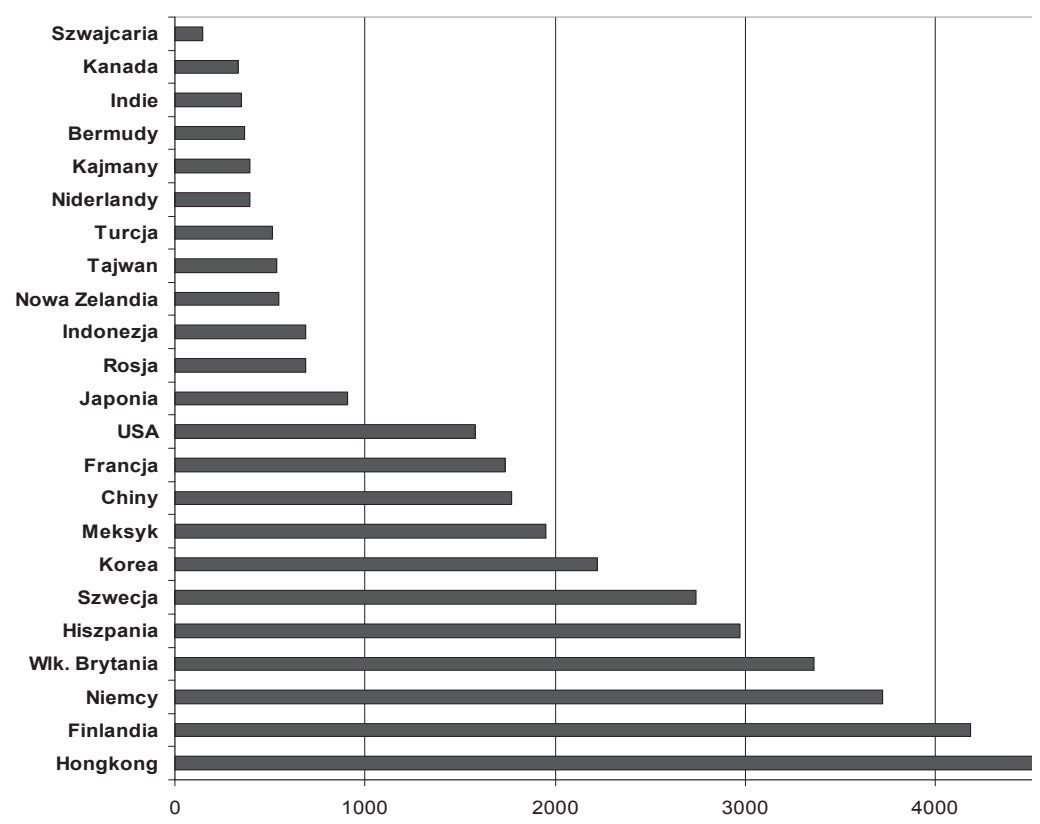

Ryc. 8. Wskaźnik zysków na 1 korporację wg państw w 2005 r.

Źródło: opracowanie własne na podstawie Infotech 100 BusinessWeek, 2005 r.

Przedstawiona analiza wskazuje, iż przestrzeń światowa stwarza bardzo zróżnicowane warunki dla lokalizacji zarządów nowoczesnych firm związanych z informacyjną fazą rozwoju społecznego. Oznacza to działanie procesów polaryzacji, które prowadzą do zróżnicowania przestrzennego liczebności siedzib korporacji, a także ich potencjału ekonomicznego oraz wynikających z niego wskaźników. Silna koncentracja firm informatycznych występuje w Stanach Zjednoczonych, - 44 korporacje osiągnęły tam 43,4\% ogółu przychodów i 49,7\% zysków. Bardzo wysokie przychody i zyski generują firmy, których siedziby znajdują się w Korei, Niemczech i na Tajwanie. Łącznie 63 firmy z wymienionych 4 państw obejmują 805,7 mld USD, tj. 66,6\% przychodów i 94,5 mld USD, tj. 67,5\% ogółu zysków. Druga grupę tworzą: Japonia, Indie, Bermudy, Kanada, Rosja, Meksyk, Hiszpania, Francja, Chiny, Wielka Brytania, Hongkong i Finlandia, z których 31 korporacji wypracowało przychody wynoszące 382,3 mld USD, tj. 31,6 ogółu przychodów oraz 428 mld USD, tj. 30,6\% ogółu zysków. Najmniejsze znaczenie w tym zakresie mają firmy pochodzące ze Szwajcarii, Kajmanów, Turcji, Holandii, Nowej Zelandii i Indonezji, które łącznie skupiają 22,5 mld USD, tj. 1,9\% przychodów i 2,7 mld USD, tj. 1,9\% ogółu zysków.

$\mathrm{Na}$ ten obraz w decydującym stopniu wpływa potencjał firm informatycznych, które mają siedzibę zarządu w danym kraju. W czołówce największych firm informatycznych, zarówno pod względem przychodów, jak i zysków, wyróżnia się IBM z siedzibą zarządu w Stanach Zjednoczonych. Innymi korporacjami amerykańskimi, które znajdują się w pierwszej dziesiątce pod tym względem, są Verizon Communications, Microsoft oraz Intel. Wśród korporacji koreańskich w ogóle badanych korporacji czwarte miejsce pod względem dochodów i drugie pod względem zysków cechuje Samsung Electronics. Spośród korporacji europejskich najwyższe pozycje pod tym względem zajmują Deutsche Telekom, France Telecom, Telefonica oraz Nokia. 
W świetle przedstawionej analizy można przyjąć, że potencjał ekonomiczny firm w przestrzeni światowej występujących na terenie poszczególnych krajów można traktować jako ważny wskaźnik określający stopień zaawansowania rozwoju gospodarki opartej o wiedzę.

\section{Literatura}

BusinessWeek Polska, 7 lipca - 3 sierpnia 2005, nr 14 (178)

Micek G., 2006, Problematyka funkcjonowania firm informatycznych w ujęciu przestrzennym, [w:] Międzynarodowe uwarunkowania rozwoju przemystu, Prace Komisji Geografii Przemysłu PTG, nr 8, red. Z. Zioło, T. Rachwał, Warszawa-Kraków, s. 139-151

Zioło Z., 2004, Ksztaltowanie się firm informatycznych jako nowych elementów struktury przestrzennej przemystu, [w:] Przemiany struktur przemysłowych, red. Z. Zioło, Z. Makieła, Prace Komisji Geografii Przemysłu PTG, nr 7, Warszawa-Kraków, s. 97-106

Zioło Z., 2006, Zróżnicowanie światowej przestrzeni przemystowej w świetle koncentracji siedzib zarzadów wiodacych korporacji, [w:] Międzynarodowe uwarunkowania rozwoju przemystu, red. Z. Zioło, T. Rachwał, Prace Komisji Geografii Przemysłu PTG, nr 8, Warszawa-Kraków, s. $9-26$

Zorska A., 2002, Ku globalizacji? Przemiany w korporacjach transnarodowych $i$ w gospodarce światowej, Wydawnictwo Naukowe PWN, Warszawa

Zorska A., 2003, „Nowa gospodarka” a globalizacja i regionalizacja, www.centrumwiedzy.edu.pl, ostatni dostęp 16.11.2007

\section{Spatial concentration of world IT companies}

The article analyses the spatial concentration of world IT companies. They have been described in terms of their varied potential, types and extent of activity and the degree of global concentration. Research included the world's top 100 largest IT companies, which jointly receive a revenue of USD 1.2 trillion, turning a profit of USD 140 billion. The revenue of the different companies ranged from USD 524.7 million to USD 97.0 billion. The leaders among those businesses are IBM Corporation, Verizon Communications, Deutsche Telekom and Samsung Electronics, which concentrate USD 313.0 billion, that is 25.9 per cent of the total revenue that the largest IT corporations receive. The joint profit of all the analysed IT companies is USD 140.1 billion and it ranges from USD 12.4 million to 11.2 billion. The corporations that make the highest profit are Microsoft, Samsung Electronics and IBM, which jointly earn USD 28.9 billion, which makes up 20.6 per cent of total profit. The analysed corporations are marked by a strong correlation between the revenue and profit - its index is 0.832 .

The analysed enterprises represent 8 types of business in the IT sector: telecommunication, hardware, software, semiconductors, telecommunication devices, services, distributors and Internet companies. The leaders among them are 24 telecommunication companies, whose joint revenue is USD 428.2 billion, that is 35.4 per cent of the total income, and the profit is USD 46.5 billion, that is 33.2 per cent of total profit.

The United States has a high concentration of IT companies, 44 of which have reached 43.4 per cent of total revenue and 49.7 per cent of total profit. Companies located in Korea, Germany and Taiwan yield very high revenue and profit. Sixty-three companies from those four countries jointly yield USD 805.7 billion, that is 66.6 per cent of revenue, and USD 94.5 billion, that is 67.5 per cent of total profit. The least important in this respect are the companies located in Switzerland, the Cayman Islands, Turkey, the Netherlands, New Zealand and Indonesia, which jointly concentrate USD 22.5 billion, that is 1.9 per cent of revenue and USD 2.7 billion, that is 1.9 per cent of total profit. 